\title{
Analisis Penerapan Akuntansi Pertanggungjawaban Dalam Penilaian Kinerja Pada PT. Taspen (Persero) KC Bogor
}

\author{
Dwinia Lulu Hasna dan Rachmawati Rachman \\ Program Studi Akuntansi, Institut Bisnis dan Informatika Kesatuan \\ Bogor, Indonesia \\ E-Mail: rachmawati.kesatuan@gmail.com
}

\begin{abstract}
Performance is one of the supporting factors in achieving the objectives of the company. Good or poor management performance can be seen from performance assessments. One that can be used as the basis of performance assessment is responsibility accounting. The research discusses performance assessment of the responsibility center. The responsibility center a company leader or a branch head. The measurement of managers performance is the assessment of the responsibility center. The purpose of this research is to determine the application of responsibility accounting in the performance assessment of responsibility center at PT. Taspen (Persero) KC Bogor. The method used by the authors in this research is a comparative descriptive analysis, which is to analyse the organizational structure, budget drafting, cost classification, account code arrangement, and responsibility report as well as assessment of the performance of the responsibility center using relevant data available and compared with the underlying theory. From the results of the study showed that the implementation of responsibilty accounting in the performance assessment of responsibility center can be said good enough. The company should identify the type of responsibility center to facilitate the performance assessment of managers.
\end{abstract}

Keywords: accounting responsibility, performance assessment, responsibility center

\begin{abstract}
ABSTRAK
Kinerja merupakan salah satu faktor pendukung tercapainya tujuan perusahaan. Baik atau buruknya kinerja manajemen dapat dilihat dari penilaian kinerja. Salah satu yang dapat dipergunakan sebagai dasar penilaian kinerja adalah akuntansi pertanggungjawaban. Penelitian ini membahas penilaian kinerja terhadap pusat pertanggungjawaban. Pusat pertanggungjawaban yang dimaksud adalah pimpinan perusahaan atau disebut dengan kepala cabang. Pengukuran hasil kinerja para manajer merupakan penilaian pusat pertanggungjawaban. Tujuan penelitian ini adalah untuk mengetahui penerapan akuntansi pertanggungjawaban dalam penilaian kinerja pusat pertanggungjawaban pada PT. Taspen (Persero) KC Bogor. Metode yang digunakan penulis dalam penelitian ini adalah analisis deskriptif komparatif, yaitu menganalisis struktur organisasi, penyusunan anggaran, penggolongan biaya, susunan kode rekening, dan laporan pertanggungjawaban serta penilaian kinerja pusat pertanggungjawaban dengan menggunakan data relevan yang tersedia dan dibandingkan dengan landasan teori yang ada. Dari hasil penelitian tersebut menunjukkan bahwa penerapan akuntansi pertanggungjawaban dalam penilaian kinerja pusat pertanggungjawaban dapat dikatakan cukup baik. Perusahaan sebaiknya melakukan pengidentifikasian jenis pusat pertanggungjawaban untuk mempermudah penilaian kinerja para manajer.
\end{abstract}

Kata Kunci: akuntansi pertanggungjawaban, penilaian kinerja

JIAKES

Jurnal Ilmiah Akuntansi Kesatuan Vol. 8 No. 1, 2020 pg. 67-76 ISSN $2337-7852$ E-ISSN $2721-3048$ 
Accounting

Responsibility and

Performance

\section{PENDAHULUAN}

Baik atau buruknya kinerja manajemen akan terlihat melalui penilaian kineja. Salah satu yang dapat dipergunakan sebagai dasar penilaian kinerja yaitu akuntansi pertanggungjawaban. Akuntansi pertanggungjawaban yang diterapkan secara baik dapat memberikan kemudahan bagi pimpinan perusahaan dalam pengambilan keputusan manajemen, sehingga menimbulkan kepuasan kerja manajer karena berhasil menyelesaikan suatu pekerjaan. Penilain kinerja ini dapat dilakukan dengan dua tahap menurut Mulyadi (2001) yaitu tahap persiapan dan tahap penilaian.

Menurut Mulyadi (2012) akuntansi pertanggungjawaban merupakan suatu sistem akuntansi yang disusun sedemikian rupa sehingga pengumpulan dan pelaporan biaya dan pendapatan dilakukan sesuai dengan pusat pertanggungjawaban dalam organisasi, dengan tujuan agar dapat ditunjuk orang atau kelompok orang yang bertanggungjawab atas penyimpangan biaya dan pendapatan yang dianggarkan. Untuk menerapkan akuntansi pertanggungjawaban terdiri dari lima syarat yang harus dipenuhi menurut Mandak (2013) yaitu: adanya struktur organisasi secara tegas harus menetapkan wewenang dan tanggung jawab setiap tindakan yang dilakukan manajemen, setiap tingkat manajemen harus menyusun anggaran biaya, adanya penggolongan biaya disesuaikan antara biaya yang dapat dikendalikan dan biaya yang tidak dapat dikendalikan oleh setiap manajemen di dalam suatu organisasi, kewenangan pengendalian pusat pertanggungjawaban dilakukan dengan adanya susunan kode rekening suatu perusahaan, dan sistem pelaporan biaya kepada manajer yang bertanggungjawab.

Akutansi pertanggujawaban dapat memantau seluruh aktivitas organisasi serta dapat mengetahui unit kerja yang bertanggung jawab atas aktivitas tersebut dan menentukan organisasi mana yang tidak berjalan dengan efisien. Agar suatu aktivitas atau usaha lain yang dilakukan dapat terencana/ terprogram sesuai dengan tujuan yang hendak dicapai, maka diperlukan sarana berupa struktur oganisasi yang didalamnya mencakup pendelegasian wewenang. Dalam organisasi perusahaan, penentuan daerah pertanggungjawaban dan manajer yang bertanggungjawab dilaksanakan dengan menetapkan pusat-pusat pertanggungjawaban dan tolak ukur kinerjanya. Dengan diterapkan akuntansi pertanggungjawaban secara baik pada setiap aktivitas organisasi atau usaha lainnya dapat memperjelas peran setiap unit atau pihak mana yang bertanggung jawab atas pekerjaannya karena ada struktur organisasi yang mencakup tugas-tugasnya dan tanggung jawabnya, dapat mempermudahkan untuk menyusun anggaran karena bertujuan untuk menentukan peran setiap manajer dalam melaksanakan aktivitas organisasinya, dapat digunakan sebagai penilaian kinerja manajer dalam melaksanakan peran yang mereka miliki dalam organisasi perusahaan. Dengan demikian jika perusahaan tidak menerapkan akuntansi pertanggungjawaban yang akan terjadi terhadap perusahaan tersebut adalah adanya penyelewangan terhadap pembagian tugas dan tanggung jawab yang diberikan oleh manajer, tidak memungkin memantau suatu kegiatan secara keseluruhan secara objektif, dapat menimbulkan kecurangan terhadap penyusunan anggaran dan penyusunan laporan keuangan, dan jika tidak melakukan penilaian atas kinerja maka di dalam suatu organisasi akan terjadi perilaku yang menyimpang atau perilaku yang tidak dinginkan.

PT. Taspen (Persero) merupakan Badan Usaha Milik Negara (BUMN) yang bergerak di bidang asuransi tabungan hari tua dan dana pensiun bagi ASN dan Pejabat Negara yang kegiatan utamanya bertugas melayani transaksi pembayaran klim kepada peserta pensiun secara kas atau tunai maupun secara transfer atau cek. Dalam menjalankan kegiatannya, pimpinan perusahaan tidak memungkinkan untuk memantau secara langsung seluruh kegiatan usaha perusahaannya. Sehingga sangat penting untuk melakukan pendelegasian wewenang ke tingkat pimpinan yang berada di bawahnya, dengan adanya laporan pertanggungjawaban yang objektif, relevan, dan tepat waktu dari masing-masing bidangnya. Pusat pertanggungjawaban pada PT. Taspen (Persero) KC Bogor adalah pimpinan perusahaannya. Di mana pimpinan perusahaan itu bertanggung jawab atas pengawasan kegiatan operasionalnya. Manajer yang bertanggung jawab pada 
tugas masing-masing akan dinilai kinerjanya. Hasil kinerja manajer tersebut menentukan keefektivitas dan keefisienan suatu pencapaian tujuan perusahaan. Pengukuran hasil kinerja para manajer ini disebut dengan penilaian kinerja pimpinan perusahaan. Untuk dapat mengetahui manajer menjalankan tugas dan tanggung jawabnya dengan baik maka perusahaan perlu menerapkan akuntansi pertanggungjawaban.

Beberapa penelitian terdahulu yang mendukung topik penelitian yang akan diangkat oleh penulis adalah Diana Septiani ngrum (2018) tentang Penerapan Akuntansi Pertanggungjawaban Dengan Anggaran Sebagai Alat Pengendalian Biaya Pada PT Duta Indonesia Djaya. Hasil penelitiannya menunjukkan bahwa PT Duta Indonesia Djaya belum memenuhi semua syarat akuntansi pertanggungjawaban, karena belum adanya pemisahan biaya antara biaya terkendali dan biaya tidak terkendali. Kemudian Giovanni Redempta Christa Gresta Sudarsono (2015) tentang Analisis Akuntansi Pertanggungjawaban Sebagai Alat Penilaian Kinerja Manajemen Studi Kasus Pada Hotel XYZ. Hasil penelitiannya menunjukkan bahwa penerapan akuntansi pertanggungjawaban belum berjalan dengan baik, karena semua syarat akuntansi pertanggungjawabannya belum berjalan dengan baik dan tidak adanya pengelompokkan pusat pertanggungjawaban terhadap struktur organisasi. Selanjutnya Poni Septarina (2017) tentang Analisis Akuntansi Pertanggungjawaban Dalam Penilaian Kinerja Pusat Pendapatan Pada PT. Kebayoran Pharma. Hasil penelitiannya menunjukkan bahwa penerapan akuntansi pertanggungjawabannya belum berjalan dengan baik, karena dalam penyusunan anggaran menggunakan pendekatan top down di mana penyusunannya tidak melibatkan karyawan. Penilaiain kinerja pusat pendapatan pada PT. Kebayoran Pharma sudah dikatakan cukup memadai karena dalam laporan pertanggungjawaban sudah adanya anggaran realisasi, selisih serta persentase pencapaian.

Berdasarkan uraian latar belakang masalah, maka dapat diindentifikasi masalah yaitu sebagai berikut: (1) Bagaimana penerapan akuntansi pertanggungjawaban pada PT. Taspen (Persero) KC Bogor? (2) Bagaimana penilaian kinerja pusat pertanggungjawaban pada PT. Taspen (Persero) KC Bogor?

\section{METODOLOGI PENELITIAN}

Penelitian ini dilakukan di PT Taspen ( Persero) Kantor Cabang Bogor, yang terletak di jalan Raya Pajajaran No.17A, Bogor Utara. PT Taspen (Persero) Kantor Cabang Bogor ini adalah Badan Usaha Milik Negara Indonesia yang bergerak di bidang asuransi tabungan hari tua dan dana pensiun bagi ASN dan pejabat negara. Penulis melakukan penelitian ini dimulai sejak bulan November Tahun 2019. Data primer yang penulis kumpulkan adalah hasil wawancara berupa tanya jawab dengan manajer dan staf karyawan PT. Taspen (Persero) KC Bogor mengenai akuntansi pertanggungjawaban, proses penyusunan anggaran dan tahap penilaian kinerja. Data sekunder yang digunakan dalam penelitian ini adalah gambaran umum perusahaan, struktur organisasi, laporan realisasi anggaran dan laporan pertanggungjawaban serta laporan pencapaian target kinerja pada PT. Taspen (Persero) KC Bogor. Metode Analisis untuk penelitian ini adalah menggunakan pendekatan kualitatif. Dalam penelitian ini secara spesifik dibagi menjadi 2 bagian, yaitu Analisis Deskriptif dan Analisis Komparatif.

\section{HASIL DAN PEMBAHASAN}

\section{Penerapan Akuntansi Pertanggungjawaban Pada PT. Taspen (Persero) KC Bogor}

Untuk menerapkan akuntansi pertanggungjawaban secara baik, perusahaan harus memenuhi lima syarat dari akuntansi pertanggungjawaban sebagai berikut yaitu:

1. Struktur Organisasi. Setiap struktur organisasi yang dimiliki perusahaan tentunya berbeda-beda sesuai dengan kegiatan organisasinya. Untuk menjalankan kegiatan organisasi tersebut dengan lancar maka perusahaan tidak akan pernah lepas dari tugas dan tanggung jawabnya. Syarat pertama dalam menerapkan akuntansi pertanggungjawaban secara baik yaitu adanya struktur organisasi. Dalam struktur organisasi menunjukkan kerangka atau bagan yang menggambarkan hubungan kerja seperti kedudukan, tugas, dan tanggung jawab yang terdapat di suatu perusahaan.

\section{Accounting \\ Responsibility and \\ Performance}


Melalui struktur organisasi tersebut tugas, wewenang dan tanggung jawab setiap Responsibility and Performance bidangnya dapat diketahui dengan jelas dan tepat.

Dalam struktur organisasi PT. Taspen (Persero) KC Bogor telah digambarkan secara jelas jenjang wewenang, tugas dan tanggung jawabnya tiap bidangnya. Dengan pemberian wewenang pada manajer dan unit kerja lainnya dapat mengetahui hal apa yang harus di pertanggungjawabkan. Selain itu, struktur organisasi yang dipakai oleh PT. Taspen (Persero) KC Bogor merupakan jenis struktur organisasi fungsional, dimana struktur tersebut dibagi berdasarkan fungsinya masing-masing. Dengan adanya pembagian tugas berdasarkan fungsinya, maka akan membuat unit kerja mengetahui dengan jelas tugasnya masing-masing. PT. Taspen (Persero) KC Bogor membuat pembagian tugasnya secara tertulis yang disebut job description. Dimana dalam job description ini menjelaskan tugas, wewenang, dan tanggung jawab setiap bidangnya yang terdapat pada struktur organisasi. Dalam akuntansi pertanggungjawaban, pusat pertanggungjawaban dapat dikatakan sebagai unit kerja dalam organisasi yang dipimpin seseorang manajer yang bertanggung jawab. Pusat pertanggungjawaban pada PT. Taspen (Persero) KC Bogor adalah pimpinan perusahaan atau disebut dengan Kepala Cabang. Struktur organisasi PT. Taspen (Persero) KC Bogor sudah dikatakan cukup baik karena adanya penggambaran secara jelas dan tepat pembagian tugas, wewenang, dan tanggung jawabnya pada setiap bidangnya yang tertera di job description. Struktur organisasi perusahaan telah memenuhi syarat utama akuntansi pertanggungjawaban yaitu adanya struktur organisasi, di mana pengertian dari struktur organisasi merupakan gambaran dari pusat pertanggungjawaban yang dimiliki oleh perusahaan. Pusat pertanggungjawaban yang dimiliki PT. Taspen (Persero) KC Bogor ini adalah Kepala Cabang dan belum melakukan pengidentifikasian atas jenis pusat pertanggungjawaban.

2. Penyusunan Anggaran. Syarat kedua dalam menerapkan akuntansi pertanggungjawaban yaitu harus menyusun anggaran. Anggaran merupakan penjabaran rencana kerja yang dinyatakan dalam jumlah uang dari masing-masing pusat pertanggungjawaban di Kantor Pusat maupun Kantor Cabang untuk periode 1 Januari sampai dengan 31 Desember, dimana anggaran kolektif secara perusahaan dinamakan Rencana Kerja dan Anggaran Perusahaan (RKAP). Penyusunan anggaran ini berfungsi sebagai pengendalian dan pengawasan. Selain itu, anggaran dapat dijadikan sebagai suatu penilaian kinerja pimpinan pusat pertanggungjawaban, dimana anggaran tersebut merupakan dasar untuk melakukan penilaian kinerja. Tujuan penyusunan anggaran pada PT. Taspen (Persero) KC Bogor adalah untuk mengetahui jumlah biaya yang akan dibutuhkan oleh masing-masing tiap bidangnya dalam membiayai seluruh kegiatan operasional yang akan dilaksanakan dan memprediksi kegiatan operasional serta keuangan perusahaan dimasa yang akan datang.

PT. Taspen (Persero) KC Bogor dalam proses penyusunan anggaran ini dilakukan dengan menggunakan pendeketan bottom-up, dimana anggaran perusahaan tersebut dibuat terlebih dahulu oleh unit kerja paling bawah lalu ke manajer per bidangnya untuk dievaluasi dan disusun oleh bidang keuangan selama tiga bulan sekali kemudian anggaran perusahaan tersebut dikirimkan ke kantor pusat. Sebelum dikirimkan ke kantor pusat untuk meminta pengesahan oleh dewan direksi, anggaran perusahaan tersebut harus mendapatkan persetujuan dari Kepala Cabang. Proses penyusunan tersebut menggunakan aplikasi SAP (System Application and Product In Data Processing) pada menu e-Budgeting yang dilaksanakan dengan bertujuan untuk mengoptimalkan perencanaan kerja, penetapan anggaran, penyesuaian POA (Plan Of Action) serta evaluasi pelaksanaan RKAP. Dalam penyusunan anggaran perusahaan pada PT. Taspen (Persero) KC Bogor ini berbasis risiko, dimana risiko tersebut dianalisis apakah terdapat penyimpangan yang terjadi kemudian membuat keputusan dari hasil analisis tersebut dan diputuskan oleh pengguna anggaran.

Penyusunan Anggaran merupakan kegiatan yang mengawali suatu siklus anggaran. Pada tahap ini perusahaan menyusun rencana kerja dan anggaran sebagai penjabaran atas visi dan misi, serta strategi perusahaan. Penyusunan yang baik disusun berdasarkan asumsi-asumsi yang realistis, relevan, dan mempertimbangkan analisis risiko. Tahap 
selanjutnya adalah tahap pelaksanaan. Pada tahap ini, perusahaan melaksanakan (merealisasikan) rencana kerja yang telah disusun di tahap sebelumnya. Tahap terakhir dalam siklus anggaran adalah tahap evaluasi. Pada dasarnya, kegiatan evaluasi dilaksanakan secara bersama selama pelaksanaan (realisasi). Kegiatan evaluasi meliputi pengawasan dan pengendalian atas tahap pelaksanaan serta penyerapan anggaran, sekaligus penilaian terhadap pencapaian target kinerja yang dilakukan dengan membandingkan antara rencana dengan realisasi, serta anggaran. Kegiatan evaluasi dilakukan secara periodik yang akan menghasilkan umpan balik, baik bagi pelaksanaan anggaran di sisa tahun berjalan maupun bagi penyusunan anggaran tahun berikutnya. Kegiatan evaluasi ini akan membantu dalam perbaikan dan peningkatan kualitas penyusunan RKAP.

Laporan realisasi anggaran periode tahun 2019 PT Taspen KC Bogor dapat dikatakan baik dan terkendali karena dalam laporan tersebut mengalami peningkatan tiap bulannya dapat dilihat berdasarkan pencapaian. Pada bulan Maret pencapaian yang terjadi sebesar $20.20 \%$, kemudian pada bulan Juni pencapaiannya sebesar $50.40 \%$, kemudian pada bulan September pencapaiannya sebesar $69.10 \%$ dan terakhir pada bulan Desember pencapaian yang terjadi sebesar $92.02 \%$. Peningkatan yang terjadi karena PT. Taspen (Persero) KC Bogor dalam satu tahun menargetkan jumlah biaya yang dikeluarkan dan jika target biaya tersebut melebihi batas target maka anggaran tersebut tidak tersedia dan dapat dikatakan tidak baik dan tidak terkendali pengecualian pada beban gaji seperti pengobatan dan penggantian pengobatan. Target biaya yang dikeluarkan selama satu tahun ini tidak menentu jumlahnya sehingga dalam satu tahun ini dilakukan evaluasi selama tiga bulan sekali untuk membahas tentang biaya yang sudah digunakan dan biaya yang belum untuk digunakan. Laporan realisasi anggaran beban belanja modal ini hanya dilakukan sekali tiap tahun sehingga tidak melakukan pengevaluasian selama tiga bulan sekali dalam penyusunannya. Pada laporan tersebut menunjukkan target biaya yang dikeluarkan sudah baik digunakan dalam pemakaiannya sehingga tidak menimbulkan penyimpangan yang terjadi.

\section{Penggolongan Biaya}

Syarat ketiga dalam menerapkan akuntansi pertanggungjawaban yaitu adanya penggolongan biaya, dimana biaya dibagi menjadi dua yaitu biaya terkendali dan biaya tidak terkendali. Penggolongan biaya bertujuan untuk membantu para manajer mengetahui biaya mana yang harus dipertanggungjawabkan dan membantu dalam mengendalikan biaya tersebut. Biaya terkendali adalah biaya yang dipengaruhi dan dikendalikan oleh seorang manajer dalam jangka waktu tertentu. Sedangkan biaya tidak terkendalikan adalah biaya yang tidak dapat dipengaruhi dan dikendalikan oleh seorang manajer dalam jangka waktu tertentu. PT. Taspen (Persero) KC Bogor tidak melakukan penggolongan biaya terkendali maupun biaya tidak terkendali pada penyusunan laporan realisasi anggaran dan laporan pertanggungjawaban.

\section{Kode Rekening}

Syarat keempat dalam menerapkan akuntansi pertanggungjawaban yaitu adanya susunan kode rekening. Dalam penyusunan kode rekening ini diklasifikasikan untuk setiap perkiraan yang ada. Pengkodean rekening ini bertujuan untuk memudahkan dalam penyusunan laporan keuangan perusahaan karena sudah mengklarifikasi kode rekening perusahaan sesuai dengan jenis perkiraannya. Dalam penyusunan pengkodean rekening ini ada beberapa cara yaitu dengan menggunakan huruf, angka atau kombinasi antara keduanya yaitu angka dengan huruf. PT. Taspen (Persero) KC Bogor telah melakukan pengkodean rekening untuk setiap perkiraan dengan baik. Kode perkiraan pada PT. Taspen (Persero) KC Bogor disusun secara konsisten tiap tahunnya dan tidak pernah berubah. Klasifikasi kode rekening ini sudah dikaitkan dengan pusat pertanggungjawaban yang ada di dalam perusahaan, dimana pusat pertanggungjawaban tersebut ialah Kepala Cabang maka terdapat kewenangan serta memberikan informasi mengenai kapan dan dimana terjadinya suatu biaya serta manajer yang bertanggungjawab atas terjadinya biaya tersebut. Contoh pengklasifikasi kode rekening pada PT. Taspen (Persero) KC Bogor sebagai berikut:

\section{Accounting \\ Responsibility and \\ Performance}

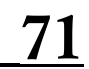


Accounting

Responsibility and

Performance

72
612 Beban

61230

612301

612301101

Beban Usaha

Beban Gaji

Gaji Dasar

Berdasarkan uraian di atas, dapat dikatakan bahwa kode rekening pada PT. Taspen (Persero) KC Bogor telah sesuai dengan syarat penerapan akuntansi pertanggungjawaban karena dalam susunan kode rekening tersebut sudah melakukan pengklasifikasian perkiraan dengan baik dan jelas serta sudah dikaitkan dengan pusat pertanggungjawaban yaitu Kepala Cabang yang ada di dalam perusahaan maka terdapat kewenangan serta memberikan informasi mengenai kapan dan dimana terjadinya suatu biaya dan manajer yang bertanggungjawab atas terjadinya biaya tersebut.

5. Laporan Pertanggungjawaban

Syarat terakhir dalam menerapkan akuntansi pertanggungjawaban yaitu adanya sebuah laporan pertanggungjawaban untuk dipertanggungjawabkan oleh manajer yang bertanggung jawab. Laporan pertanggungjawaban dalam akuntansi pertanggungjawaban berfungsi untuk setiap kepala perbidangnya dapat melakukan pengawasan dan pengendalian. Laporan pertanggungjawaban adalah laporan yang berisi tentang rincian biaya yang diterima dan rincian biaya yang telah dikeluarkan dalam satu periode waktu dimana periode yang digunakan tersebut adalah bulan.

PT. Taspen (Persero) KC Bogor telah membuat laporan pertanggungjawaban seperti neraca saldo yang dilakukan oleh manajer pada bagian keuangan. Jenis laporan ini dapat membuat pimpinan perusahaan lebih fokus terhadap penyimpangan yang terjadi. Jika terjadi suatu penyimpangan baik dari luar perusahaan maupun dari dalam perusahaan, perusahaan akan menindaklanjuti dengan melakukan tindakan koreksi dan melakukan pemeriksaan kembali atas laporan tersebut. Penyusunan atas laporan pertanggungjawaban dilakukan tiap sebulan sekali kemudian laporan pertanggungjawaban tersebut dikirimkan ke kantor pusat pada tanggal satu bulan berikutnya, sebelum dikirimkan laporan tersebut harus mendapatkan persetujuan dari Kepala Cabang. Sebelum diserahkan kepada Kepala Cabang dibuat terlebih dahulu oleh bagian keuangan dan laporan tersebut dibuat secara teratur, tepat waktu, serta adanya perbandingan antara biaya periode sekarang dengan biaya periode sebelumnya. Periode yang dimaksud adalah bulan. Laporan pertanggungjawaban pada PT. Taspen (Persero) KC Bogor ini sudah menyesuaikan struktur organisasi dengan dikaitkannya pusat pertanggungjawaban dimana Kepala Cabang tersebut sebagai pusat pertanggungjawaban. Pada laporan pertanggungjawaban dibuat secara sederhana agar mudah dimengerti oleh penggunanya.

Laporan pertanggungjawaban pada PT. Taspen (Persero) KC Bogor telah sesuai dengan syarat akuntansi pertanggungjawaban karena di dalam laporan pertanggungjawaban tersebut sudah menyesuaikan struktur organisasi dengan mengaitkan unit kerja yang bertanggungjawab, penyusunannya pun dengan tepat waktu, jelas dan mudah dimengerti oleh penggunanya. Laporan pertanggungjawaban tersebut dapat dikatakan baik dan terkendali karena pada akun kas besar dalam saldo akhirnya berjumlah nol sehingga tidak melebihi kebijakan perusahaan yaitu Rp. 500.000. Begitupun dengan akun Bank BRI dalam saldo akhirnya berjumlah sebesar Rp. 271.144 sehingga tidak melebihi Rp. 500.000 yang sudah ditetapkan dalam kebijakan perusahaan karena BRI merupakan mitra dari PT. Taspen (Persero) KC Bogor. Jika pada akun kas besar dan akun Bank BRI melebihi kebijakan perusahaan maka laporan pertanggungjawaban tersebut dapat dikatakan tidak baik dan tidak terkendali.

\section{Penilaian Kinerja Pusat Pertanggungjawaban}

PT. Taspen (Persero) KC Bogor dalam melakukan penilaian kinerja terhadap pimpinan pusat pertanggungjawaban berdasarkan pada pengukuran hasil kerja para manajer. Penilaian kinerja dalam PT. Taspen (Persero) KC Bogor ini dilakukan untuk mengevaluasi rencana kerja selama satu tahun sesuai dengan kriteria yang telah ditetapkan. Kriteria yang telah ditetapkan oleh PT. Taspen (Persero) KC Bogor dalam menilai kinerjanya yaitu pencapaian atas target kinerja yang telah ditetapkan. Target 
kinerja yang telah ditetapkan oleh PT. Taspen (Persero) KC Bogor adalah tugas dari masing-masing kinerja dan selesai tepat waktu. Dalam setengah semester, perusahaan melakukan bimbingan kinerja guna untuk evaluasi terhadap manajer dan karyawan sedangkan untuk penilaian kinerja dilakukan selama enam bulan sekali dengan berdasarkan pada laporan realisasi anggaran. Penilaian kinerja ini bertujuan untuk menilai kinerja para manajer guna untuk meningkatkan keefektivitasan dan keefisienan kinerja manajer dan mendorong perilaku kinerja yang baik dalam pencapaian tujuan perusahaan. PT. Taspen (Persero) KC Bogor dalam melakukan penilaian kinerja atas anggaran ini dilakukan perbandingan antara anggaran dengan realisasinya. Selisih antara anggaran dan realisasinya dicantumkan dalam laporan realisasi anggaran yang dibuat oleh perusahaan. Setelah mengetahui selisih tersebut perusahaan akan mencari penyebab timbulnya penyimpangan tersebut baik dari dalam perusahaan atau dari luar perusahaan sehingga perusahaan akan menganalisis atas penyimpangan yang terjadi.

Sebagai tindak lanjut dalam penilaian kinerja ini, perusahaan harus menegakkan perilaku yang diinginkan dan mencegah perilaku yang tidak diinginkan atau menyimpang, sehingga PT. Taspen (Persero) KC Bogor menetapkan suatu kebijakan berupa pemberian penghargaan maupun hukuman. Penghargaan yang diberikan oleh perusahaan berupa kenaikan gaji, bonus dari pencapaian target kinerja yang telah ditetapkan dan kenaikan jabatan sedangkan hukuman yang diberikan berupa peringatan tertulis maupun lisan. Jika salah satu manajer dan unit kerja lainnya tidak mencakup target kinerja yang telah ditetapkan oleh PT. Taspen (Persero) KC Bogor ini maka akan mempengaruhi tunjangan dan penilaian kinerjanya. Selain itu penilain kinerja ini dilakukan untuk memberikan motivasi terhadap seluruh unit kerja guna untuk meningkatkan kinerjanya menjadi perilaku yang diinginkan dalam perusahaan. Evaluasi kinerja manajer di PT. Taspen (Persero) KC Bogor ini harus dilakukan untuk memantau unit kerja melaksanakan tugasnya secara baik dalam pencapaian target kinerja yang telah ditetapkan. Penilaian kinerja dapat dilakukan dengan dua tahap, yaitu tahap persiapan dan tahap penilaian. Pada tahap persiapan, langkah-langkah yang dilakukan sebagai berikut:

1. Penentuan daerah pertanggungjawaban dan manajer yang bertanggungjawab

Dalam penentuan daerah pertanggungjawaban dan manajer yang bertanggungjawab ada tiga hal yang harus dipenuhi meliputi: kriteria penetapan tanggung jawab, tipe pusat pertanggungjawaban dan karakteristik pusat pertanggungjawaban. Dalam struktur organisasi PT. Taspen (Persero) KC Bogor ini telah membagi jelas bagian kerja antara manajer dan tingkat bawahnya pada bagian tugas, wewenang dan tanggung jawabnya masing-masing tertera pada job description. Dalam penelitian ini, PT. Taspen (Persero) KC Bogor mengidentifikasi pusat pertanggungjawabannya adalah pimpinan perusahaan atau disebut dengan Kepala Cabang sehingga PT. Taspen (Persero) KC Bogor belum melakukan mengidentifikasikan tipe pusat pertanggungjawabannya.

2. Menetapkan kriteria yang dipakai untuk mengukur kinerja

Pada PT. Taspen (Persero) KC Bogor yang kegiatannya selalu berhubungan dengan pembayaran klaim atas asuransi dan pensiun tiap bulannya. Pimpinan perusahaan PT. Taspen (Persero) KC Bogor dalam menetapkan kriteria untuk mengukur kinerjanya adalah menganalisa laporan realisasi anggaran dengan target kinerja yang telah ditetapkan. Untuk menetapkan kriteria dalam mengukur kinerja ada lima perspektif sebagai berikut: Keefektivitasan produk dan proses, Fokus pada pelanggan, Fokus tenaga kerja, Kepemimpinan, Keuangan dan pasar

3. Pengukuran kinerja sesungguhnya

Pada PT. Taspen (Persero) KC Bogor dalam melakukan pengukuran kinerja sesungguhnya adalah acuan terhadap laporan realisasi anggaran. Dengan laporan tersebut, perusahaan dapat mengukur kinerja masing-masing unit kerja. Laporan realisasi anggaran adalah laporan yang berisi mengenai perbandingan antara anggaran dengan realisasinya. Jika dalam laporan realisasi anggaran tersebut tidak sesuai dengan target kinerja yang telah ditetapkan oleh perusahaan maka akan mempengaruhi penilaian
Responsibility and Performance

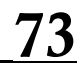


Accounting

Responsibility and

Performance

74

kinerja tersebut tetapi jika yang tidak sesuai target hanya satu maka tidak akan berpengaruh terhadap penilaian kinerja.

Setelah melakukan tahap persiapan, tahap selanjutnya adalah melakukan tahap penilaian yang dapat dilakukan sebagai berikut:

1. Pembandingan kinerja sesungguhnya dengan sasaran yang telah ditetapkan sebelumnya

Kriteria yang telah ditetapkan oleh PT. Taspen (Persero) KC Bogor adalah laporan realisasi anggaran. Sasaran PT. Taspen (Persero) KC Bogor adalah indikator target kinerja yang sudah ditetapkan. Cara perusahaan untuk mencapai sasaran secara konsisten harus sesuai dengan visi dan misi yang ditetapkan. Kepala Cabang sebagai pusat pertanggungjawaban akan mendapatkan berupa laporan pencapaian kinerja dari setiap manajer per bidangnya seperti Bidang Layanan dan Manfaat, Bidang Keuangan serta Bidang Umum dan SDM yang berada di bawah tingkatannya yang dibuat oleh Bidang Layanan dan Manfaat. Kepala Cabang dapat mengevaluasi tiap tiga bulan sekali dan melakukan penilaian kinerja unit kerja tiap enam bulan sekali dengan dilihat dari laporan pencapian target kinerja tesebut. Laporan pencapaian target kinerja merupakan laporan berisi perbandingan anggaran dengan target kinerja yang telah ditetapkan. Dengan adanya laporan pencapaian kinerja tersebut hal ini akan membantu Kepala Cabang dalam meningkatkan keefektifitasan kinerja dan meningkatkan citra perusahaan yang baik di masa yang akan datang.

2. Penentuan penyebab timbulnya penyimpangan, kinerja sesungguhnya dari yang telah ditetapkan dalam standar atau kriteria

Penyebab timbulnya terjadi penyimpangan dalam berbagai situasi di lingkungan kerjanya yaitu tergantung pada cara individu masing-masing. Penyebab penyimpangan yang terjadi karena lemahnya penilaian kinerja maka mengakibatkan perbedaan nilai sehingga menimbulkan perilaku yang tidak diinginkan, terjadi persaingan yang tidak sehat dalam memperoleh penghargaan, kesalahan dalam berkomunikasi merupakan penyimpangan yang sering terjadi karena dalam berkomunikasi dapat menemukan perbedaan arti pada kalimat, bahasa yang tidak dapat dimengerti atau sulit dipahami oleh unit kerja sehingga menimbulkan perbedaan pengetahuan, dan berbagai keragaman sifat individu masing-masing, serta dapat menimbulkan individu mempertahankan pendiriannya dan tidak bersedia menerima pendapat, pikiran orang lain. Selain itu, dalam laporan realisasi anggaran pada PT. Taspen (Persero) KC Bogor tidak ada timbulnya penyimpangan yang terjadi Hal tersebut dikarenakan laporan realisasi anggarannya terkendali disebabkan karena semua biaya yang dikeluarkan tidak melebihi batas target biaya yang sudah ditentukan oleh perusahaan sehingga dalam melakukan pengevaluasian selama tiga bulan sekali mengalami pencapaian yang sesuai dengan target ditetapkan. Dalam hal ini biaya yang terjadi pada perusahaan ditekankan oleh pimpinan perusahaan.

3. Penegakan perilaku yang diinginkan dan tindakan yang digunakan untuk mencegah perilaku yang tidak diinginkan

Dalam menegakan perilaku yang diinginkan dan pencegahan perilaku yang tidak diinginkan merupakan suatu keharusan bagi perusahaan untuk melakukan hal tersebut karena dimana perilaku dapat mempengaruhi kinerja seseorang seperti sikap manusia terhadap pekerjaan, rekan kerja, serta kerja sama antar rekan kerjanya dan lainnya sebagainya. Pada PT. Taspen (Persero) KC Bogor dalam menegakkan perilaku yang diinginkan adalah dengan cara memberikan penghargaan dan melakukan bimbingan kinerja tiap tiga bulan sekali. Dalam pemberian penghargaan ini diberikan kepada unit kerja yang telah berhasil menyelesaikan tugasnya dalam pencapaian target yang telah ditetapkan oleh perusahaan maupun yang melakukan perbaikan pada bagian yang sebelumnya melakukan kesalahan.

\section{PENUTUP}

Berdasarkan hasil penelitian dan pembahasan mengenai penerapan akuntansi pertanggungjawaban dalam penilaian kinerja terhadap pusat pertanggungjawaban pada PT. Taspen (Persero) KC Bogor, dapat disimpulkan sebagai berikut: 
1. Penerapan akuntansi pertanggungjawaban pada PT. Taspen (Persero) KC Bogor dapat dikatakan belum baik secara sempurna dikarenakan belum memenuhi semua syaratnya. Dalam syarat tersebut menunjukkan bahwa dalam struktur organisasi PT. Taspen (Persero) KC Bogor sudah melakukan pembagian jelas tugas, wewenang, dan tanggung jawab sesuai dengan bidangnya yang tertera pada job decsription tetapi dalam struktur organisasi tersebut belum melakukan pengindetifikasian jenis pusat pertanggungjawabannya, penyusunan laporan realisasi anggaran sebagai penilaian kinerja para manajer perbidangnya setiap tahun selama tiga bulan sekali untuk pengevaluasian, anggaran tersebut disusun berdasarkan pendekatan bottom up, yaitu sudah melibatkan bawahan dalam penyusunan anggaran secara keseluruhan sehingga dapat menghasilkan anggaran yang lebih baik dan tepat agar seluruh unit kerja merasa bertanggung jawab atas anggaran tersebut, penggolongan biaya antara biaya terkendali dengan biaya tidak terkendali tidak dilakukan dalam penyusunan anggaran, susunan kode rekening ini bertujuan untuk memudahkan dalam penyusunan laporan keuangan perusahaan sehingga kepala cabang dapat memberikan informasi mengenai kapan dan dimana terjadinya suatu biaya kemudian yang terakhir dari syarat penerapan akuntansi pertanggungjawaban yaitu menyusun laporan pertanggungjawaban. Laporan pertanggungjawaban pada PT. Taspen (Persero) KC Bogor berupa neraca saldo yang berisi rincian biaya yang diterima dan rincian biaya yang telah dikeluarkan dalam satu bulan yang bertanggung jawab adalah manajer bidang keuangan.

2. Dalam penerapan akuntansi pertanggungjawaban, laporan realisasi anggaran merupakan salah satu acuan dalam penilaian kinerja para manajer. Sedangkan untuk mengukur kinerja ada lima kriteria yang ditetapkan yaitu: efektivitas produk dan proses, fokus pada pelanggan, fokus tenaga kerja, kepemimpinan, serta keuangan dan pasar. Sehingga laporan realisasi anggaran dan lima kriteria tersebut dirinci menjadi laporan pencapaian target kinerja. Laporan tersebut dapat membantu kepala cabang untuk meningkatkan keefektifitasan kinerja dan meningkatkan citra perusahaan yang baik di masa yang akan datang. Pengukuran hasil kinerja para manajer ini merupakan penilaian kinerja pusat pertanggungjawaban atau disebut dengan kepala cabang. Selain dilihat dari laporan PT. Taspen (Persero) KC Bogor dalam melakukan penilaian kinerja diilhat berdasarkan penegakkan perilaku yang diinginkan dan mencegah perilaku yang tidak diinginkan. Dalam menegakkan perilaku yang diinginkan adalah dengan cara memberikan penghargaan dan melakukan bimbingan kinerja tiap tiga bulan sekali. Penghargaan yang diberikan dapat berupa kenaikan gaji, kenaikan jabatan, bonus uang, liburan keluarga dan cincin emas berbentuk logo Taspen untuk masa kerja yang bekerja selama 10, 20, dan 30 tahun sedangkan untuk mencegah perilaku yang tidak diinginkan adalah dengan memberikan hukuman bagi yang melanggar berupa sebuah peringatan lisan maupun tertulis seperti penurunan gaji, penurunan jabatan atau dengan pemberhentian kerja. Penilaian pusat pertanggungjawaban pada PT. Taspen (Persero) KC Bogor dapat dikatakan cukup baik walaupun belum melakukan pengindetifikasian jenis pusat pertanggungjawabannya dapat dilihat berdasarkan laporan realisasi anggaran dengan membandingkan target yang telah ditetapkan menunjukkan bahwa bidang yang tidak sesuai dengan target yang telah ditetapkan maka dapat ditutupi oleh bidang yang sudah sesuai target yang telah ditetapkan.

\section{DAFTAR PUSTAKA}

Amirullah. 2015. Manajemen Strategi Teori Konsep Kinerja, Edisi Pertama, Mitra Wacana Media, Jakarta.

Blocher, David dan Cokins. 2012. Manajemen Biaya, Salemba Empat, Jakarta. Hansen, Mowen. 2011. Akuntansi Manajerial, Penerbit Salemba Empat, Jakarta. Hansen, Mowen. 2012. Manajemen Biaya, Penerbit Salemba Empat, Jakarta. 
Accounting Responsibility and Performance
Hidayat, Taufik. 2015. Pengaruh Kejelasan Sasaran Anggaran, Struktur Desentralisasi dan Locus Of Control Terhadap Kinerja Manajerial, Jakarta: UIN Syarif Hidayatullah. 8(2), 148-161.

Mandak. 2013. Penerapan Akuntansi Pertanggungjawaban dengan Anggaran Sebagai Pengendalian Biaya Dinas Perhubungan Manado, Jurnal EMBAVol. I No 3: 465473.

Mawarni dan Retrani. 2016. Penerapan Akuntansi Pertanggungjawaban Sebagai Alat Penilaian Kinerja Pusat Biaya, Jurnal Ilmu Riset Akuntansi Vol.5 No 2.

Mulyadi. 2001. Akuntansi Manajemen: Konsep, Manfaat, dan Rekayasa, Edisi Ketiga, Mitra Wacana Media, Jakarta.

Mulyana, M., 2012. Consumer Behaviour: Sukses Dengan Memahami Konsumen.

Munawar, A. and Marpaung, B.S., 2013. Pengaruh Arus Kas Operasi Terhadap Peningkatan Kemampulabaan dan Pertumbuhan Perusahaan STUDI KASUS PADA PT. HOLCIM INDONESIA, TBK. Jurnal Ilmiah Manajemen Kesatuan, 1(3), pp.213-217.

Mulyadi. 2012. Sistem Akuntansi, Penerbit Salemba Empat, Jakarta.

Moeheriono. 2012. Pengukuran Kinerja Berbasis Kompetensi. Raja Grafindo Persada, Jakarta

Nafarin M. 2013. Penganggaran Perusahaan, Edisi 3, Salemba Empat, Jakarta.

Purba, J.H.V. and Munawar, A., 2008. Kajian Dampak Pelatihan terhadap Kinerja Karyawan. Jurnal Ilmiah Ranggagading (JIR), 8(2), pp.95-102.

Rivai, Veithzal. 2011. Manajemen Sumber Daya Manusia Untuk Perusahaan Dari Teori Dan Praktik, PT. Raja Grafindo Persada, Jakarta.

Rudianto. 2013. Akuntansi Manajemen, Penerbit Erlangga, Jakarta.

Samryn. 2012. Akuntansi Manajemen: Informasi Biaya Untuk Mengendalikan Aktivitas Operasi Dan Informasi. Edisi Pertama, Kencana, Jakarta.

Sasongko dan Parulian. 2015. Anggaran, Penerbit Salemba Empat, Jakarta.

Setiawan, B., Puspitasari, R. and Manurung, T.M.S., 2016. The existence of Islamic banking in Indonesia from non-muslims perceptions. ASEAN Marketing Journal, pp.81-96.

Simanjuntak. 2011. Manajemen Evaluasi Kinerja, Edisi 3, Fakultas UI, Jakarta.

Sigar dan Elim. 2014. Penerapan Informasi Akuntansi Pertanggungjawaban Sebagai Alat Penilaian Kinerja Pada PT. Bank Sulut Cabang Tondano, Jurnal EMBA Vol.2 No.I: 499-509.

Sedarmayati. 2011. Manajemen Sumber Daya Manusia, Reformasi Birokrasi dan Manajemen Pegawai Negeri Sipil, cetakan kelima, PT Refika Aditama, Bandung

Septarina, Poni. 2017. Analisis Akuntansi Pertanggungjawab Dalam Penilaian Kinerja Pusat Pendapatan Pada PT. Kebayoran Pharma, Universitas Muhammadiyah Palembang.

Septianingrum, Diana. 2018. Penerapan Akuntansi Pertanggungjawaban Dengan Anggaran Sebagai Alat Pengendalian Biaya Pada PT Duta Indonesia Djaya, Institut Agama Islam Negeri Surakarta .

Sudarsono G. 2015. Analisis Akuntansi Pertanggungjawaban Sebagai Alat Penilaian Kinerja Manajemen Studi Kasus Pada Hotel XYZ, Universitas Sanata Dharma.

Sugiri. 2015. Akuntansi Manajemen Sebuah Pengantar, Edisi 5, UPP STIM YKPN, Jogjakarta.

Tarmizi, Selvyana, dan Purnomo. 2010. Pengendalian Biaya dalam Hubungannya dengan Akuntansi Pertanggungjawaban (Studi Kasus Pada Hotel Indra Puri di Bandar Lampung), Jurnal Akuntansi \& Keuangan Vol.1 N0. I : 95-108 